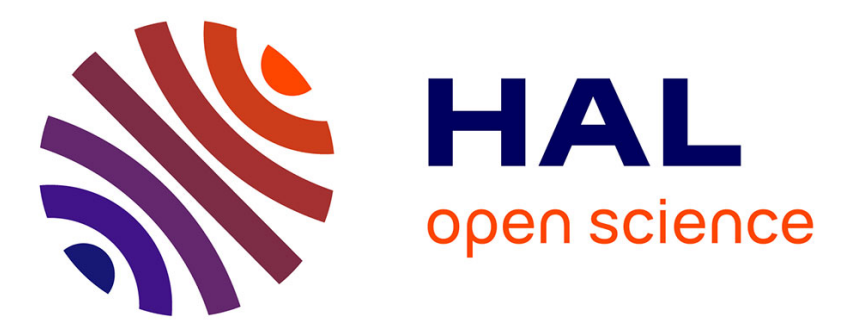

\title{
Genetic drift during the spread phase of a biological invasion
}

\author{
Nadège Belouard, Jean-Marc Paillisson, Adrien Oger, Anne-Laure Besnard, \\ Eric Petit
}

\section{> To cite this version:}

Nadège Belouard, Jean-Marc Paillisson, Adrien Oger, Anne-Laure Besnard, Eric Petit. Genetic drift during the spread phase of a biological invasion. Molecular Ecology, 2019, 28 (19), pp.4375-4387. 10.1111/mec.15238 . hal-02304433

\section{HAL Id: hal-02304433}

\section{https://hal-univ-rennes1.archives-ouvertes.fr/hal-02304433}

Submitted on 19 Nov 2019

HAL is a multi-disciplinary open access archive for the deposit and dissemination of scientific research documents, whether they are published or not. The documents may come from teaching and research institutions in France or abroad, or from public or private research centers.
L'archive ouverte pluridisciplinaire HAL, est destinée au dépôt et à la diffusion de documents scientifiques de niveau recherche, publiés ou non, émanant des établissements d'enseignement et de recherche français ou étrangers, des laboratoires publics ou privés. 
DR. NADĖGE BÉLOUARD (Orcid ID : 0000-0002-7968-7735)

Article type : Original Article

\section{Genetic drift during the spread phase of a biological invasion}

Running title: Genetic drift during species spread

Nadège Bélouard ${ }^{1,2 *}$, Jean-Marc Paillisson ${ }^{1}$, Adrien Oger ${ }^{1}$, Anne-Laure Besnard ${ }^{2}$, Eric J. Petit ${ }^{2}$

${ }^{1}$ UMR ECOBIO, CNRS, Université de Rennes 1, 35042 Rennes, France

${ }^{2}$ UMR 985, ESE, Ecology and Ecosystem Health, INRA, Agrocampus Ouest, 35042 Rennes Cedex, France

*Corresponding author. E-mail: nadege.belouard@gmail.com

\section{Abstract}

Recent theoretical and experimental models have evidenced the role played by evolution during species spread, and particularly question the influence of genetic drift at range edges. By investigating the spread of an aquatic invader in patchy habitats, we quantified genetic drift and explored its consequences on genetic diversity and fitness. We examined the interplay of gene flow and genetic drift in 36 populations of the red swamp crayfish, Procambarus clarkii, in a relatively recently invaded wetland area (30 years, Brière, northwestern France). Despite the small spatial scale of our study $\left(15 \mathrm{~km}^{2}\right)$, populations were highly structured according to the strong barrier of land surfaces and revealed a clear pattern of colonisation through watercourses. Isolated populations exhibited small effective sizes and low dispersal rates that depended on water connectivity, suggesting that genetic drift dominated in the evolution of allele frequencies in these populations. We also observed a 
significant decrease in the genetic diversity of isolated populations over only a two-year period, but failed to demonstrate an associated fitness cost using fluctuating asymmetry. This study documents the possible strong influence of genetic drift during the spread of a species, and such findings provide critical insights in the current context of profound rearrangements in species distributions due to global change.

Key-words: colonisation, effective population size, landscape genetics, range edge, range expansion, red swamp crayfish

\section{Introduction}

Understanding the ecological and evolutionary processes that occur during species range expansions is of major interest as many species are currently shifting their distribution ranges in the context of global change (Excoffier, Foll, \& Petit, 2009; Parmesan, 2006; Phillips, Brown, \& Shine, 2010b; Walther et al., 2002). The early view of colonisation waves spreading at constant rates (Fisher, 1937; Skellam, 1951) has been challenged by empirical observations documenting that spread is influenced by a variety of processes such as long-distance dispersal, biotic interactions, environmental heterogeneity, and evolution (Hastings et al., 2005; Sexton, McIntyre, Angert, \& Rice, 2009). Recent theoretical and experimental works have particularly investigated the evolution occurring during range expansions, both at the phenotypic and genetic levels (Peischl, Kirkpatrick, \& Excoffier, 2015; Phillips et al., 2010b; Phillips, Brown, Webb, \& Shine, 2006; Slatkin \& Excoffier, 2012; Williams, Snyder, \& Levine, 2016). A major consequence of evolution at leading edges is that species spread rates accelerate but are also relatively unpredictable (Ochocki \& Miller, 2017; Phillips, Brown, \& Shine, 2010a; Weiss-Lehman, Hufbauer, \& Melbourne, 2017; Williams, Kendall, \& Levine, 2016). Researchers generally see the signature of selection in this pattern, notably through spatial sorting, though conclusive evidence of adaptation during spread remains rare (Bertelsmeier \& Keller, 2018; Colautti \& Lau, 2015). Genetic drift is another important evolutionary force at play in nonequilibrium situations (Keller \& Taylor, 2008; Slatkin \& Excoffier, 2012), and range expansions are thus expected to be accompanied by large stochastic rearrangements of allele frequencies, with potential phenotypic consequences (Excoffier et al., 2009; Klopfstein, Currat, \& Excoffier, 2006; Peischl et al., 2015). 
The magnitude of genetic drift is related to the effective size of populations (Charlesworth, 2009; Wang, Santiago, \& Caballero, 2016), and effective population size estimates are more reliable when temporal samples are available (Gilbert \& Whitlock, 2015). Genetic drift indeed occurs over time, but also across space in the case of range expansions (Slatkin \& Excoffier, 2012). Its effects are detectable both at the individual level, with decreases in individual heterozygosity favouring the expression of deleterious mutations that potentially decrease individual fitness, and at the populational level, with the depletion of genetic diversity, increased differentiation, and decreases in population growth rates directly related to the individual inbreeding load (Charlesworth \& Willis, 2009; Peischl \& Excoffier, 2015; Willi, Fracassetti, Zoller, \& Van Buskirk, 2018). The consequences of genetic drift can thus be evaluated by analysing heterozygosity-fitness correlations (Peischl \& Excoffier, 2015; Szulkin, Bierne, \& David, 2010). Indirect proxies of fitness are needed because individual fitness is usually difficult to assess in natural populations. For instance, the inability for an organism to buffer its development against random environmental disturbances leads to a pattern of random differences in both sides of bilateral characters, called fluctuating asymmetry (Leung \& Forbes, 1996; Palmer \& Strobeck, 1986). Fluctuating asymmetry can be used as a proxy for fitness, though the strength of this relationship is heterogeneous (Clarke, Brand, \& Whitten, 1986; Lens, Dongen, Kark, \& Matthysen, 2002; Leung \& Forbes, 1996).

Biological invasions are colonisations that occur at contemporary time scales (Sax et al., 2007), and evolution can be a major lever in their success (Hastings et al., 2005; Lawson Handley et al., 2011; Lee, 2002; Prentis, Wilson, Dormontt, Richardson, \& Lowe, 2008). They are thus particularly suited to assess the strength of evolutionary forces during spatial spread. Biological invasions are now recognized as a major and increasing form of global change (Hulme, 2009; Lockwood, Hoopes, \& Marchetti, 2007), and it is critical to understand the evolutionary processes at play in these situations. We studied the red swamp crayfish (Procambarus clarkii), an aquatic invasive species native from the south-central USA, which is now found in many regions of the world (Capinha, Leung, \& Anastácio, 2011; Souty-Grosset et al., 2016). In Europe, it was first introduced for aquaculture in Spain in the early 1970's, and it invaded most of west-European countries afterwards (Savini et al., 2010; SoutyGrosset et al., 2016). The species indeed acclimates to a wide range of aquatic environments, and generally spreads rapidly once introduced (e.g. Capinha, Brotons, \& Anastácio, 2013; Lodge et al., 
2012). Recent works investigated the genetic structure of populations of the red swamp crayfish at large spatial scales, and highlighted the predominant role of anthropogenic dispersal in its spread across regions (Huang, Tang, Cai, Lin, \& Wu, 2017; Yi et al., 2018). Besides, tracking studies evidenced its capacity to travel several kilometers (Aquiloni, Ilhéu, \& Gherardi, 2005; Barbaresi, Santini, Tricarico, \& Gherardi, 2004; Gherardi \& Barbaresi, 2000; Gherardi, Tricarico, \& Ilhéu, 2002), and to resist desiccation well enough to cross terrestrial habitats (Banha \& Anastácio, 2014; Ramalho \& Anastácio, 2015). However, this body of literature taught little about the range expansion of the species by active dispersal, and the associated evolutionary dynamics remain unstudied (but see Messager \& Olden, 2019 about another invasive crayfish species). Recent empirical studies suggest a strong resistance of terrestrial areas to the spread of red swamp crayfish in discrete aquatic habitats (Paulson \& Martin, 2014; Tréguier, Roussel, Bélouard, \& Paillisson, 2018). Metapopulations of this invasive crayfish are thus a stimulating support for analysing the spatio-temporal dynamics of evolutionary forces during a colonisation.

Our study progressed through three related steps. First, we used landscape genetics to characterise the spread of the red swamp crayfish in pond networks where the species had naturally colonised waterbodies (Tréguier et al., 2018). In particular, we evaluated two competing hypotheses, because the role of terrestrial dispersal in the spread of this invasive species is currently controversial: (1) crayfish disperse overland, or (2) crayfish preferentially disperse through watercourses. Second, we looked for bottlenecks, and quantified the strength of genetic drift by estimating effective population sizes $\left(\mathrm{N}_{\mathrm{e}}\right)$ based on temporal data. We expected bottlenecks signatures to be more frequent and $\mathrm{N}_{\mathrm{e}}$ to decrease towards the invasion front because of founder effects (Estoup, Beaumont, Sennedot, Moritz, \& Cornuet, 2004; Peter \& Slatkin, 2015). Finally, we assessed whether genetic drift had genetic and fitness consequences in crayfish populations. Assuming that the invasion front remained stable throughout the study, and if effective population sizes are lower at the invasion front, edge populations should undergo a higher loss of genetic diversity and increased genetic differentiation over time, and they should exhibit lower fitness (i.e. higher levels of fluctuating asymmetry) as compared to source populations. We also expected to observe a heterozygosity-fitness correlation across populations (Palmer \& Strobeck, 1986; Peischl \& Excoffier, 2015). 


\section{Materials and methods}

\section{Study location, sampling, molecular characterisation, and basic statistics}

The study was conducted within the Regional Natural Park of Brière (RNPB), northwestern France $\left(47^{\circ} 23^{\prime} \mathrm{N}, 02^{\circ} 12^{\prime} \mathrm{W}\right.$ ), in an area of $5 \mathrm{~km} \times 3 \mathrm{~km}$ (Fig. 1) comprising more than 200 ponds in a hedgerow landscape, and located between the marsh of Mès $\left(16 \mathrm{~km}^{2}\right)$ and the marsh of Brière $(90$ $\mathrm{km}^{2}$ ). Temporary watercourses flow into the marshes, but aquatic continuity is completely disrupted between the two marshes, so that ponds are clustered into two networks following catchment delineations (Fig. 1, see a more detailed description of the study site in Tréguier et al., 2018). The marshes of Brière and Mès and their networks of ponds are called the network of Brière and the network of Mès hereafter, respectively. Historical records suggest that the red swamp crayfish was introduced only once in the marsh of Brière in the early 1980's when individuals escaped from a nearby crayfish farm that was closing down (Fig. 1). Crayfish were first recorded in the marsh of Mès in 2003, some 20 years after this introduction. The actual distribution of crayfish in the study area suggests that it colonised ponds mainly via active dispersal from both marshes (Tréguier et al., 2018). Therefore, the working hypothesis of the present study is that marsh populations constituted the source populations for colonising the aquatic habitats of the study area, while pond populations constituted the invasion front. Recurrent monitoring since 2010 indicates that crayfish distribution in ponds is apparently stable.

Most analyses involved crayfish collected in 36 locations (six distinct stretches of marsh canals and 30 ponds) in May 2016. To perform temporal analyses of allelic frequencies, we also used crayfish sampled in a subset of 20 locations two years earlier, in May 2014 (Fig. 1). We sampled 16 to 32 crayfish per station per year, for a total of 488 individuals in 2014, and 1,039 individuals in 2016. Crayfish populations were initially classified into five categories with respect to the degree of aquatic connectivity of the station to a marsh: marsh populations (coded MB and MM, for marsh of Brière and marsh of Mès, respectively), populations of ponds connected to a marsh (either located within the maximum annual flooded area of a marsh or directly connected to a watercourse flowing into a marsh, coded $\mathrm{CB}$ and $\mathrm{CM}$ ), and populations of ponds isolated from the rest of the hydrological network 
(coded I, 4 to $278 \mathrm{~m}$ away from a watercourse or the marsh of Brière, Fig. 1 and Table S1, Supporting information).

DNA was extracted from abdomen muscle using NucleoSpin Tissue kits (Macherey-Nagel, Düren, Germany) for the samples collected in 2014, and using the Chelex protocol (Walsh, Metzger, \& Higuchi, 1991) for the samples collected in 2016. DNA was amplified at nine microsatellite loci (described in Belfiore \& May, 2000: PclG4, PclG7, PclG15, PclG16, PcG17, PclG27, PclG32, PclG37, PclG48) with a touchdown PCR program: $95^{\circ} \mathrm{C}$ for $15 \mathrm{~min}$, then 20 cycles at $94^{\circ} \mathrm{C}$ for 45 seconds, $60^{\circ} \mathrm{C}$ for 45 seconds, and $72^{\circ} \mathrm{C}$ for 60 seconds, with annealing temperatures decreasing by $0.5^{\circ} \mathrm{C}$ every cycle from 60 to $50^{\circ} \mathrm{C}$. The PCR reaction continued for 20 additional cycles at $94^{\circ} \mathrm{C}$ for 45 seconds, $50^{\circ} \mathrm{C}$ for 45 seconds, and $72^{\circ} \mathrm{C}$ for 60 seconds. Amplified PCR products were sequenced by the GENTYANE platform (INRA, Clermont-Ferrand, France), and individuals were genotyped in GeneMapper (Applied Biosystems, Foster City, CA, USA).

Statistical analyses were conducted using R 3.5.0 (R Core Team, 2018) unless otherwise indicated, and supplemental packages are specified therein. All permutation tests were done with 10,000 permutations. Microsatellite genotypes were handled with the R package adegenet (Jombart, 2008). Deviation from Hardy-Weinberg proportions was tested for each locus in each population with an exact permutation test using the R package pegas (Paradis, 2010). Each population was described using allelic richness $\left(\mathrm{A}_{\mathrm{r}}\right.$, based on a minimum of 15 individuals), gene diversity $\left(\mathrm{H}_{\mathrm{S}}\right)$, Wright's inbreeding coefficient $\left(\mathrm{F}_{\mathrm{IS}}\right)$, and a population-specific index of differentiation relative to the entire pool ( $\beta_{\mathrm{WT}}$, Weir \& Goudet, 2017) using the R package hierfstat (Goudet \& Jombart, 2015). We also calculated pairwise $\mathrm{F}_{\mathrm{ST}}$, whose significance was determined using permutation tests included in hierfstat. We tested the significance of the variation of $\mathrm{A}_{\mathrm{r}}$ and $\mathrm{H}_{\mathrm{s}}$ against the five population categories and networks, and that of $\beta_{\mathrm{WT}}$ against the three population categories, using permutation ANOVAs, then, when significant, pairwise permutation $t$ tests between categories with "fdr" p-values correction for multiple testing (R package RVAideMemoire, Hervé, 2019).

\section{Pathways and timing of gene flow}

Two competing hypotheses were tested regarding pathways of gene flow. The first tested whether crayfish disperse with equal ease in aquatic and terrestrial habitats (Marques, Banha, Águas, \& 
Anastácio, 2015; Ramalho \& Anastácio, 2015), with patterns of genetic variation congruent with an isolation by distance (IBD). The second hypothesis supported the idea that watercourses played the role of dispersal corridors in a matrix of terrestrial habitats (Paulson \& Martin, 2014; Tréguier et al., 2018). In the latter case, patterns of genetic variation would rather correspond to least-cost paths (LCP, Adriaensen et al., 2003) through watercourses.

We tested both one- and two-dimensional IBD models as the first was more appropriate for populations of ponds located along watercourses, whereas the second better fitted marsh populations (more details in Rousset, 1997). Geographic distances were represented by raw or log-transformed Euclidean distances between ponds for one- or two-dimensional IBD, respectively. For LCP models, a logical binary cartography of the study area (terrestrial vs. aquatic habitats) was designed using ArcGIS 10.1 (Environmental Systems Research Institute, Redlands, California, USA 2011), a land use map (BD ORTHO 2009), and additional field validations. Least-cost distances between stations were calculated with five different costs of terrestrial dispersal $(5,10,20,50$, and 100) versus a cost of aquatic dispersal fixed at one. The different combinations of terrestrial/aquatic dispersal costs are hereafter termed cost ratios 5/1,10/1,20/1,50/1 and 100/1. IBD models thus corresponded to the cost ratio 1/1. All distances were calculated using the R packages raster (Hijmans, 2017) and gdistance (van Etten, 2017). We tested the correlations between genetic distances (linearised pairwise $\mathrm{F}_{\mathrm{ST}}$, $\left.\mathrm{F}_{\mathrm{ST}} /\left(1-\mathrm{F}_{\mathrm{ST}}\right)\right)$ and each type of geographic distance using permutation Mantel tests using the $\mathrm{R}$ package adegenet (Jombart, 2008). Additionally, we assumed that if the spatial spread of crayfish in the area actually resulted from independent introductions in each pond network, and not from a unique introduction in the marsh of Brière, correlations between genetic and geographic distances should be stronger when separating the two networks. Therefore, correlations were tested on all sampled populations together, and then separately on the populations of each network.

Gene flow, when limited in distance relative to the sampled area, results in isolation-by-distance patterns in both equilibrium and non-equilibrium situations (Slatkin, 1993). Therefore, IBD on its own does not report whether gene flow is currently occurring, or occurred, for instance during a colonisation process, and stopped afterwards (Gracianne et al., 2016). We estimated current dispersal rates $\left(\mathrm{m}_{\mathrm{e}}\right)$ between ponds and marshes, using the maximum likelihood method implemented in MLNe 1.0 (Wang \& Whitlock, 2003). The method is based on the temporal variation in allele frequencies of 
a focal population, and allele frequencies of a reference, source population. It has the major advantage of estimating migration rates along with effective population sizes. The genotypes from the three stations of each marsh in 2014 were pooled to define the two marshes as source populations for the ponds of their respective networks.

\section{Traces of bottlenecks and effective population sizes}

We first searched for traces of recent bottlenecks as signatures of recent founder events using the graphical method described in Luikart et al. (1998) using samples collected in 2014. This method is based on the elimination of rare alleles that occurs during a bottleneck, that leaves a histogram of allelic frequencies with a lower number of rare alleles as compared to higher-frequency alleles right after a bottleneck. It was preferred over other existing methods because we expected the bottlenecks to have occurred recently, and that reduces the power of more classical statistical tests or model-based methods (e.g. Leblois et al., 2014). This method has another advantage. It does not make any assumption about the mutational process, which is also misleading bottleneck detection in many situations (Leblois et al., 2014), and for which we had no information for the microsatellites we used. We then estimated $\mathrm{N}_{\mathrm{e}}$ using the likelihood-based temporal method implemented in $\mathrm{MLN}_{\mathrm{e}}$ (Wang \& Whitlock, 2003), since simulations proved it was one of the most accurate methods across different demographic scenarios, migration rates and population sizes (Gilbert \& Whitlock, 2015). $\mathrm{N}_{\mathrm{e}}$ was estimated along with $\mathrm{m}_{\mathrm{e}}$ for populations sampled both in 2014 and 2016. $\mathrm{N}_{\mathrm{e}}$ for marsh (source) populations was calculated using the same method but assuming no immigration (Wang \& Whitlock, 2003). We tested the significance of variations in $\mathrm{N}_{\mathrm{e}}$ against the three population categories, using a permutation ANOVA, and pairwise permutation $t$ tests between categories with "fdr" p-values correction for multiple testing (package RVAideMemoire, Hervé, 2019).

\section{Consequences of genetic drift}

We evaluated the effects of genetic drift on allele frequencies by testing changes in genetic diversity $\left(\mathrm{A}_{\mathrm{r}}\right.$ and $\left.\mathrm{H}_{\mathrm{S}}\right)$ and in isolation of populations $\left(\beta_{\mathrm{WT}}\right)$ between 2014 and 2016 using permutation paired $t$-tests. We also tested the idea that bottlenecks are still acting by assessing the evolution of the number of alleles in the first two frequency classes ([0;0.1[ and [0.1;0.2[) between 2014 and 2016 in each population with a permutation paired $t$-test. 
Fluctuating asymmetry (FA) was estimated on the crayfish sampled in 2014 (individuals with a total length $>60 \mathrm{~mm}$ from the tip of the rostrum to the end of the telson, $\mathrm{n}=325$ ), including 88 individuals from the populations of isolated ponds, 150 from the populations of connected ponds, and 87 from the marsh populations. First, each individual was photographed in ventral view, its legs removed and placed in the corresponding order and on the corresponding side of the body, with a Canon EOS 1000D digital camera in a standardised way. Second, based on these photographs, individuals were sexed, and four bilateral morphological traits were measured: the length of the second antennal article, of the merus of the cheliped (P1), of the third (P3), and of the fourth (P4) pereiopods, using Image J (Rasband, 2012). The measurements were repeated after a few days by the same observer to assess their reliability. The body parts not fully apparent on some photographs inflated measurement error (measurement 1 - measurement 2), and the regeneration of one chela or marked differences in the positioning of the right and left legs inflated right-left asymmetry (right measurement - left measurement, noted R-L), therefore these obvious outliers were discarded. The final dataset approached normal distributions both for the measurement error and the right-left asymmetry for each trait. As the signed R-L values were poorly correlated between traits (Pearson correlation coefficient, $r=-0.09-0.22$ ), all traits were kept for subsequent analyses. Evidence for size dependence was shown in the asymmetry of the leg traits, but not of the second antennal article (linear regressions, unsigned R-L values against individual body length, $p<0.05$, except for the second antennal article, $p$ $=0.15)$. Indices of FA were thus corrected by the mean trait value, i.e. $\mid R-L / /(R+L) / 2)($ Palmer $\&$ Strobeck, 1986). Finally, the significance of FA was tested using a side · individual ANOVA for each trait and population category (Palmer \& Strobeck, 1986). FA (the interaction term between "side" and "individual") was significant in all cases $(\mathrm{p}<0.001$, Table S2, Supporting Information). The measurement error represented between 7.5 and $12.0 \%$ of FA for the leg traits, and between 26.9 and $63.8 \%$ for the second antennal article (Table S2, Supporting Information); consequently, subsequent FA analyses were carried out only on leg traits. Differences in FA between categories of crayfish populations, and also directly between crayfish populations, were tested with a MANOVA, using the three FA indices as dependent variables. Finally, the significance of the heterozygosity-fitness correlation was tested across all populations using linear regressions of FA indices against multilocus heterozygosity (MLH) following the method in Szulkin et al. (2010) described hereafter. We 
calculated MLH as the proportion of heterozygous loci in an individual (individual number of heterozygous loci/number of genotyped loci), divided by the mean expected heterozygosity of typed loci (Coltman, Pilkington, Smith, \& Pemberton, 1999) to account for missing data. It was calculated using the function genhet (Coulon, 2010). We calculated the mean and variance of MLH $(\hat{\bar{H}}$ and $\hat{\sigma}$ ${ }^{2}(\mathrm{H})$, respectively), the regression slope and the variance of FA over MLH $\left(\hat{\beta}_{W, H}\right.$ and $\hat{r}^{2}{ }_{W, H}$, respectively) and an estimation of identity disequilibrium $\left(\hat{g_{2}}\right)$. The variance of heterozygosity explained by inbreeding $\left(\hat{r}_{W, f}^{2}\right)$, and the variance of fitness explained by inbreeding $\left(\hat{r}_{\mathrm{H}, f}^{2}\right)$, and fitness, were then calculated as:

$$
\hat{r}_{W, f}^{2}=\frac{\hat{r}^{2} W, H}{\hat{r}_{H, f}^{2}}=\frac{\hat{r}^{2}{ }_{W, H}}{\hat{g}_{2}} \frac{\hat{\sigma}^{2}(\mathrm{H})}{\hat{H}^{2}}
$$

and

$$
\hat{r}_{H, f}^{2}=\frac{\hat{r}^{2} W, H}{\hat{r}^{2}{ }_{W, f}}
$$

\section{Results}

\section{Genetic variation}

Missing genotypes represented $4.2 \%$ and $1.5 \%$ of the 2014 and 2016 datasets, respectively. Yearly genotypic frequencies did not show consistent deviations from Hardy-Weinberg proportions over loci or populations after Bonferroni corrections (global $\mathrm{F}_{\mathrm{IS}}$ per population are available in Table S1, Supporting Information), therefore we kept the entire dataset for further analyses. Across all populations, 79 alleles were found over the nine loci ( 3 to 13 alleles per locus). Although we only presented the population and landscape genetic analyses for 2016 because of the higher number of stations sampled that year, the samples collected in 2014 led to qualitatively identical results (not shown, but see their basic statistics in Table S1, Supporting Information).

Mean $A_{r}$ varied by a factor of two among populations (Table S1, Supporting Information), from 2.57 (I16) to 5.53 alleles per locus (MB3), and so did mean $\mathrm{H}_{\mathrm{S}}$, from 0.44 (I11 and I16) to 0.72 (MB3). In addition, mean $\mathrm{A}_{\mathrm{r}}$ varied according to population categories $(\mathrm{p}<0.001)$, in a similar way in 
the two networks; it decreased with increasing isolation from the marshes, with the highest values for the populations of marsh stations (mean $\pm \mathrm{SD}$ : $5.34 \pm 0.24$ in Brière, $4.84 \pm 0.15$ in Mès), intermediate values for the populations of ponds connected to the marshes ( $4.95 \pm 0.36$ in Brière, 4.28 \pm 0.73 in Mès) and the lowest values for the populations of isolated ponds (3.81 \pm 0.77 , Fig. 2a), though differences between categories were only statistically significant within the network of Brière. The same pattern was observed for $\mathrm{H}_{\mathrm{S}}(\mathrm{p}<0.01)$, with mean values ranging from $0.70 \pm 0.02$ and $0.71 \pm 0.01$ in the populations of the marshes of Brière and Mès, respectively, to $0.69 \pm 0.02$ and 0.64 \pm 0.09 in the populations of connected ponds of the networks of Brière and Mès, and $0.58 \pm 0.09$ in the populations of isolated ponds (Fig. 2b). Finally, the alleles present in the pond and marsh-of-Mès populations were a subset of those present in the marsh-of-Brière populations. Accordingly, the population categories were merged between networks, and only the three categories of connectivity to the marshes were considered in subsequent analyses.

\section{Pathways and timing of gene flow}

$\beta_{\mathrm{WT}}$ varied significantly with population categories $(\mathrm{p}<0.001)$. It was the lowest for the populations of the marsh stations (mean $\pm \mathrm{SD}:<0.01 \pm 0.06$ ), intermediate for the populations of connected ponds $(0.05 \pm 0.13)$, and the highest for the populations of isolated ponds $(0.18 \pm 0.12$, Fig. 3a). Pairwise $F_{S T}$ varied from -0.005 to 0.406 , and most populations were differentiated ( $89 \%$ of the 630 pairwise $\mathrm{F}_{\mathrm{ST}}$ were significant, Table S3, Supporting Information). The highest pairwise $\mathrm{F}_{\mathrm{ST}}$ values were found between the populations of isolated ponds (mean pairwise $\mathrm{F}_{\mathrm{ST}}$ isolated-isolated $=0.10 \pm 0.05$ ), even though some of them were 10-20 m apart only, and the lowest values between the populations of the stations of a same marsh (mean pairwise $\mathrm{F}_{\mathrm{ST} \text { marsh-marsh }}=0.01 \pm 0.01$ ), even if located up to $3 \mathrm{~km}$ apart (Fig. 1). Some populations connected by a watercourse were undifferentiated, and so were some populations belonging to different marshes. Isolated populations were genetically closer to those of the marsh of Brière than to those of the marsh of Mès; this supported their assignment to the network of Brière for subsequent analyses.

Genetic distances were not correlated to Euclidean distances between populations $(\mathrm{r}=-0.16, \mathrm{p}=$ 0.95, Fig. 3b) nor to these log-transformed distances $(r=-0.09, p=0.89)$. Genetic distances were better correlated to least-cost distances using aquatic pathways (Fig. 3c), and this correlation 
increased with the terrestrial/aquatic dispersal cost ratio up to a plateau above the cost ratio of 50/1 (circles in Fig. 3d). When considering the network of Brière alone, genetic distances were again not correlated to Euclidean distances $(r=-0.04, p=0.68$, squares in Fig. 3d). They were highly correlated to least-cost distances between populations, and the amount of genetic information explained increased five-fold using the cost ratio of 100/1 when compared to the model combining the two networks $(\mathrm{r}=0.54, \mathrm{p}<0.01)$. In the network of Mès, pond populations were all directly connected to watercourses or located within the flooded area of the marsh, and least-cost distances were therefore very similar whatever the cost ratio we applied. In this network, the correlation between genetic and Euclidean distances was high and significant (1-dimensional IBD: $r=0.74, p<$ $0.01 ; 2$-dimensional IBD: $r=0.72, p<0.01$ ), and so were the correlations between genetic and leastcost distances (plateau after a cost ratio of $5 / 1, r=0.83, p=0.03$ ).

Dispersal rates were not significantly different from 0 in the populations from isolated ponds and from four connected ponds (Fig. 3e). They were higher but variable for populations from the other six connected ponds. The three ponds with dispersal rates not significantly different from 1 were situated within the flooding area of the marshes.

\section{Traces of bottlenecks and effective population sizes}

The distribution of allelic frequencies in 2014 showed evidence for recent bottlenecks in several populations of isolated ponds (I4, I13, suspected for I3, I12, I14), but also of connected ponds (CM4, suspected for CB7, CM1, CM3), and of stations of the marsh of Mès (MM3, see Fig. S1). Accordingly, effective population sizes showed a strong gradient from marshes to isolated ponds $(\mathrm{p}=$ 0.01 ), with higher values recorded in marsh populations (80.1 and 85.4) as compared to the very low values in isolated pond populations (between 10.8 and 45.7) and in connected pond populations, although they were more variable in the latter category (8.3 to 93.2, Fig. 4a, Table S4).

\section{Consequences of genetic drift}

A significant decrease in $A_{r}$ was observed in two years overall populations $(p<0.05$, Fig. $4 b)$. The mean loss of $\mathrm{A}_{\mathrm{r}} \pm \mathrm{SE}$ ranged from $0.23 \pm 0.17$ allele in isolated populations, $0.13 \pm 0.29$ allele in connected ponds, to $0 \pm 0.25$ allele in marsh populations. $\mathrm{H}_{\mathrm{S}}$ did not significantly decrease (mean $\mathrm{H}_{\mathrm{S}}$ 
loss: $0.01 \pm 0.03, p=0.46$ ), and the differentiation between populations did not significantly increase (mean increase in $\beta_{\mathrm{WT}}: 0.01 \pm 0.04, \mathrm{p}=0.21$ ) over the same period. The number of rare alleles (frequency < 0.1) dropped in almost half of the populations, resulting in a marginally significant mean loss of $1.95 \pm 4.34$ alleles between 2014 and $2016(p=0.06)$, while the number of alleles with a frequency ranging from 0.1 to 0.2 remained stable (mean difference: $0.55 \pm 4.60, p=0.63$, Fig. S2).

Individual FA indices did not significantly vary according to the population category (MANOVA, Wilks' statistic $=0.95, \mathrm{p}=0.07$, Fig. $4 \mathrm{c}$ ) nor population (MANOVA, Wilk's statistic $=0.70, \mathrm{p}=$ 0.06). The heterozygosity-fitness correlations across all populations were very low and nonsignificant $\left(\mathrm{P} 1: \mathrm{R}^{2}=0.19 \%, \mathrm{p}=0.48 ; \mathrm{P} 3: \mathrm{R}^{2}=0.02 \%, \mathrm{p}=0.83 ; \mathrm{P} 4: \mathrm{R}^{2}=0.25 \%, \mathrm{p}=0.39\right)$. In particular, the variance in heterozygosity accounted for $10.8 \%$ of individual inbreeding, and the variance in inbreeding accounted for $1.7 \%, 0.2 \%$ and $2.3 \%$ of individual FA for P1, P3 and P4, respectively.

\section{Discussion}

In agreement with some theories and models of evolutionary dynamics during range expansions (e.g. Keller \& Taylor, 2008; Peischl et al., 2015), we found that genetic drift was a prominent evolutionary force during the colonisation of discrete aquatic habitats by the red swamp crayfish, though we failed to demonstrate that it had consequences on fitness using fluctuating asymmetry.

\section{Pattern of range expansion and current levels of gene flow}

The sharp decrease in the genetic diversity of crayfish populations observed from the marsh of Brière towards surrounding ponds confirmed that the invasion history began in the marshes and that the colonisation occurred towards the ponds. Founder effects during range expansions in patchy habitats indeed produce a spatial pattern analogous to genetic drift, with the allelic composition of the founded populations nested in the allelic composition of the source population (Slatkin \& Excoffier, 2012). Landscape genetics analyses indicated that two distinct invasions actually occurred from each marsh towards its respective pond network, given the pattern of decreasing allelic richness observed in both networks. We further speculate that the colonisation of the marsh of Mès likely resulted from

a secondary introduction event using an inoculum from the marsh of Brière since the allelic 
composition of the network of Mès was nested in that of the marsh of Brière. Comparable variations in the levels of genetic diversity between waterbodies were found elsewhere (Huang et al., 2017; Li et al., 2012; Paulson \& Martin, 2014; Yi et al., 2018), but such a fine genetic signal of crayfish spread was not identified, probably blurred by multiple introduction events at several locations and/or recurrent gene flow between populations after crayfish was introduced.

In the present study, the spatial arrangement of waterbodies was apparently suitable for red swamp crayfish to colonise all of them: the mean distance from a pond to the nearest neighbouring pond was $87 \pm 66 \mathrm{~m}$ (mean $\pm \mathrm{SD}$ ), and it has been estimated that crayfish could travel as far as 1,600 m overland (Banha \& Anastácio, 2014). In fact, only half of the ponds were actually colonised by crayfish after 30 years of invasion (Tréguier et al., 2018). We also found that genetic units were delineated by aquatic continuity, so that each pond harboured a distinct genetic population, even in ponds as close as $20 \mathrm{~m}$ to each other. By contrast, all stations within a marsh and the ponds connected to it seemed to be part of a single large genetic unit extending over at least $3 \mathrm{~km}$ from north to south as most genetic distances between populations were not significant. Landscape genetics analyses indicated that pond colonisation likely occurred predominantly through watercourses. A remarkable proportion of the genetic variance between populations was explained by only one variable, the aquatic or terrestrial nature of the habitat that crayfish have to cross. This is uncommon in landscape genetics (Graves, Chandler, Royle, Beier, \& Kendall, 2014; e.g. Spear, Peterson, Matocq, \& Storfer, 2005; Ferrer et al., 2016), and means that land surfaces appear to represent a strong barrier for the spread of crayfish. Because LCPs are simplistic landscape models, we reanalysed our data with isolation by resistance models. Our results hold when using, for instance, circuit theory (McRae \& Beier, 2007) to build resistance distances between crayfish populations (Fig. S3, Supporting Information). From an applied perspective, these findings notably suggest that the colonisation of new waterbodies by the red swamp crayfish could be prevented by disrupting the aquatic connections between them.

Whether the colonisation occurred as a serial colonisation from one pond to another with successive founder effects, or as a radial expansion with a decrease in the number of effective migrants with the distance to the marsh, is an unresolved question. When colonisations are followed by recurrent migration events, these two possibilities give rise to distinct patterns of genetic 
differentiation (see theoretical considerations in Slatkin, 1993). When migration rates are very low, it could still be expected that populations would be genetically closer to each other in a serial expansion, unless genetic drift modified too strongly allele frequencies, in which case either one or the other explanation could equally give rise to the observed genetic structure. Because we did not find populations to be genetically more related to each other along than between watercourses, we cannot distinguish between the two possibilities (Fig. S4).

Besides, most genetic distances were so high and dispersal rates were so low that incoming gene flow was probably inexistent in most pond populations. It is therefore probable that ponds were colonised during a given period, maybe only on one occasion, after which gene flow was interrupted, and genetic distances between pond populations increased ever since due to genetic drift. While dispersal rates were null in all isolated ponds, the considerable variation in dispersal rates in connected ponds (from 0 to 1 ) may have been related to the temporality of the aquatic connectivity between ponds, and between ponds and the marshes. Thus, the spread of the red swamp crayfish was likely highly restricted by the patchy nature of the pond networks and the resistance of terrestrial surfaces to dispersal. The next step would be to explore crayfish spread in other habitat configurations.

\section{Ecological and evolutionary consequences of genetic drift during a range expansion}

Genetic drift was very intense at the edges of the invasion (i.e. in isolated ponds), with very low effective population sizes, and a significant decrease in allelic richness over a two-year period (i.e. approximately two generations of crayfish). This finding contrasted with the less intense genetic drift found in source populations (i.e. marshes), where effective population sizes were higher, and allelic richness was the highest and stable over the study period. These findings are in line with theoretical models which predict that stochasticity in allelic frequencies is much higher at the leading edges of range expansions (Ochocki \& Miller, 2017; Peischl et al., 2015; Weiss-Lehman et al., 2017). These variations in allelic frequencies possibly indicate recent and even ongoing bottlenecks, as evidenced by the loss of rare alleles observed between 2014 and 2016; however, in the case of a range expansion they could also reflect the long-lasting effects of bottlenecks linked to the colonisation process. The observed dynamics of genetic diversity potentially bears important ecological and evolutionary 
consequences for populations located at the edges of the invasion, such as decreases in individual fitness and in population growth rates (Peischl et al., 2015; Willi et al., 2018).

We did not find a significant heterozygosity-fitness correlation (HFC), nor did we evidence any gradient of fluctuating asymmetry across population categories that would support the prediction that genetic drift caused a decrease in fitness in crayfish populations. However, the absence of a HFC is unlikely in the present case, as decreases in crayfish abundances jointly occurred in the vast majority of the sampled stations in the meantime (Table S5, Supporting Information), suggesting decreases in population growth rates. HFCs typically have low effect sizes (Chapman, Nakagawa, Coltman, Slate, \& Sheldon, 2009; Szulkin et al., 2010), and are highly context-dependent (Hendrickx, Maelfait, \& Lens, 2003; Peischl \& Excoffier, 2015; Szulkin et al., 2010); these two characteristics hamper the detection of significant relationships when statistical power or number of microsatellites are limited. Alternatively, the traits measured here could be insufficiently good proxies for fitness since the link between inbreeding and fitness was very low (see e.g. Van Dongen, 2006). A possible next step would be to explore other individual fitness metrics such as reproductive output (e.g. the number of eggs carried by females), or experimentally assess inbreeding depression. Beyond these fitness considerations, limitations in population growth rates can be linked to Allee effects (Maciel \& Lutscher, 2015; Taylor \& Hastings, 2005), but in our study case, this hypothesis is unlikely since crayfish abundances have been high in many ponds in the recent past (Table S5, Supporting Information).

Overall, this crayfish metapopulation probably first behaved like a classical invasion with a colonisation front progressing through watercourses. This functioning was expected to persist and allow the expansion to continue, but the system has likely turned into a source-sink metapopulation (see e.g. Furrer \& Pasinelli, 2016) due to migration being restricted by the patchy nature of the pond network. The dynamics of the isolated populations even make their long-term persistence questionable; as a consequence, we draw the hypothesis that they are entering a mechanism similar to an extinction vortex (Caughley, 1994; Fagan \& Holmes, 2006; Lynch, Conery, \& Burger, 1995). To date, the concept of extinction vortex has only been supported among threatened native species. Spontaneous population collapses in invasive species have already been recorded, especially on islands, but they have remained unexplained most of the time (Simberloff \& Gibbons, 2004). In such 
cases, the consequences of genetic drift on heterozygosity and in turn on fitness might be the key mechanism for local extinctions of invasive species. Alternatively, the decreases in crayfish abundance found here could reflect natural oscillations, which commonly occur in biological invasions (see Strayer et al., 2017). It is thus essential to pursue the monitoring of crayfish populations. It cannot be excluded that populations from isolated ponds could be reinforced in the future by recurrent pulses of immigration from the marshes. Such pulses could either only maintain the population as-is, or may foster the spread of the species owing to a demographic or genetic rescue (Bourne et al., 2014; Ingvarsson, 2001; Kanarek, Webb, Barfield, \& Holt, 2015; Peniston, Barfield, \& Holt, 2019). Pulses of immigration could be facilitated by extreme flooding, even though it is very unlikely that flood would connect isolated ponds to any watercourse. Such a context offers opportunities for future research on phenotypic evolution in expanding populations, and more particularly, the characterisation of dispersing phenotypes (see Clobert, Baguette, Benton, \& Bullock, 2012), and the fate of these phenotypes that are then trapped in ponds that may remain isolated from other aquatic bodies (Keller \& Taylor, 2008).

Range edges are the seat of important evolutionary changes that influence species spread (Excoffier et al., 2009; Phillips, 2015; Phillips et al., 2010b; Slatkin \& Excoffier, 2012), but the identification of the drivers of these changes still require empirical validation. The present case study supports the idea that genetic drift increases along with species range expansion and could explain the limits of species distribution in general (see also González-Martínez, Ridout, \& Pannell, 2017; Peischl et al., 2015; Willi et al., 2018). We encourage further investigations into the role played by evolutionary forces during species spread using invasive populations. Such works would clearly be essential in the context of global change and the profound rearrangements in species distributions (Simberloff, 2011; Vitousek, D’antonio, Loope, Rejmanek, \& Westbrooks, 1997).

\section{Acknowledgements}

We are indebted to the Syndicat mixte du RNPB for logistic support, and to landowners for allowing us to sample their ponds. This research was supported by the Agence Française pour la Biodiversité and the Ministère de l'Education Nationale, de l'Enseignement Supérieur et de la Recherche (PhD grant to N.B.). Crayfish were euthanised by freezing following the ethical guidelines 
stipulated in the licenses EMA/SM/13.73 and 2016/SEE-Biodiversité/070 delivered by the Préfecture de la Loire-Atlantique. We thank K. Gilbert and three anonymous reviewers for their constructive comments that improved the manuscript.

\section{References}

Adriaensen, F., Chardon, J. P., De Blust, G., Swinnen, E., Villalba, S., Gulinck, H., \& Matthysen, E. (2003). The application of 'least-cost' modelling as a functional landscape model. Landscape and Urban Planning, 64(4), 233-247. doi: 10.1016/S0169-2046(02)00242-6

Aquiloni, L., Ilhéu, M., \& Gherardi, F. (2005). Habitat use and dispersal of the invasive crayfish Procambarus clarkii in ephemeral water bodies of Portugal. Marine and Freshwater Behaviour and Physiology, 38(4), 225-236. doi: 10.1080/10236240500310195

Banha, F., \& Anastácio, P. M. (2014). Desiccation survival capacities of two invasive crayfish species. Knowledge and Management of Aquatic Ecosystems, (413), 01. doi: $10.1051 / \mathrm{kmae} / 2013084$

Barbaresi, S., Santini, G., Tricarico, E., \& Gherardi, F. (2004). Ranging behaviour of the invasive crayfish, Procambarus clarkii (Girard). Journal of Natural History, 38(22), 2821-2832. doi: 10.1080/00222930410001663308

Belfiore, N. M., \& May, B. (2000). Variable microsatellite loci in red swamp crayfish, Procambarus clarkii, and their characterization in other crayfish taxa. Molecular Ecology, 9(12), 22312234.

Bertelsmeier, C., \& Keller, L. (2018). Bridgehead effects and role of adaptive evolution in invasive populations. Trends in Ecology \& Evolution, 33(7), 527-534. doi: 10.1016/j.tree.2018.04.014

Bourne, E. C., Bocedi, G., Travis, J. M. J., Pakeman, R. J., Brooker, R. W., \& Schiffers, K. (2014). Between migration load and evolutionary rescue: dispersal, adaptation and the response of spatially structured populations to environmental change. Proceedings of the Royal Society B: Biological Sciences, 281(1778), 20132795-20132795. doi: 10.1098/rspb.2013.2795

Capinha, C., Brotons, L., \& Anastácio, P. (2013). Geographical variability in propagule pressure and climatic suitability explain the European distribution of two highly invasive crayfish. Journal of Biogeography, 40(3), 548-558. doi: 10.1111/jbi.12025 
Capinha, C., Leung, B., \& Anastácio, P. (2011). Predicting worldwide invasiveness for four major problematic decapods: an evaluation of using different calibration sets. Ecography, 34(3), 448-459. doi: 10.1111/j.1600-0587.2010.06369.x

Caughley, G. (1994). Directions in conservation biology. The Journal of Animal Ecology, 63(2), 215. doi: $10.2307 / 5542$

Chapman, J. R., Nakagawa, S., Coltman, D. W., Slate, J., \& Sheldon, B. C. (2009). A quantitative review of heterozygosity-fitness correlations in animal populations. Molecular Ecology, 18(13), 2746-2765. doi: 10.1111/j.1365-294X.2009.04247.x

Charlesworth, B. (2009). Effective population size and patterns of molecular evolution and variation. Nature Reviews Genetics, 10(3), 195-205. doi: 10.1038/nrg2526

Charlesworth, D., \& Willis, J. H. (2009). The genetics of inbreeding depression. Nature Reviews Genetics, 10(11), 783-796. doi: 10.1038/nrg2664

Clarke, G., Brand, G., \& Whitten, M. (1986). Fluctuating asymmetry: a technique for measuring developmental stress caused by inbreeding. Australian Journal of Biological Sciences, 39(2), 145. doi: 10.1071/BI9860145

Clobert, J., Baguette, M., Benton, T. G., \& Bullock, J. M. (Eds.). (2012). Dispersal ecology and evolution (1st edition). Oxford University Press.

Colautti, R. I., \& Lau, J. A. (2015). Contemporary evolution during invasion: evidence for differentiation, natural selection, and local adaptation. Molecular Ecology, 24(9), 1999-2017. doi: $10.1111 / \mathrm{mec} .13162$

Coltman, D. W., Pilkington, J. G., Smith, J. A., \& Pemberton, josephine M. (1999). Parasitemediated selection against inbred soay sheep in a free-living island population. Evolution, 53(4), 1259-1267. doi: 10.1111/j.1558-5646.1999.tb04538.x

Coulon, A. (2010). genhet: an easy-to-use R function to estimate individual heterozygosity. Molecular Ecology Resources, 10(1), 167-169. doi: 10.1111/j.1755-0998.2009.02731.x

Estoup, A., Beaumont, M., Sennedot, F., Moritz, C., \& Cornuet, J.-M. (2004). Genetic analysis of complex demographic scenarios: spatially expanding populations of the cane toad, Bufo marinus. Evolution, 58(9), 2021-2036. doi: 10.1111/j.0014-3820.2004.tb00487.x 
Excoffier, L., Foll, M., \& Petit, R. J. (2009). Genetic consequences of range expansions. Annual Review of Ecology, Evolution, and Systematics, 40(1), 481-501. doi: 10.1146/annurev.ecolsys.39.110707.173414

Fagan, W. F., \& Holmes, E. E. (2006). Quantifying the extinction vortex. Ecology Letters, 9(1), 5160. doi: 10.1111/j.1461-0248.2005.00845.x

Ferrer, E. S., García-Navas, V., Bueno-Enciso, J., Barrientos, R., Serrano-Davies, E., Cáliz-Campal, C., ... Ortego, J. (2016). The influence of landscape configuration and environment on population genetic structure in a sedentary passerine: insights from loci located in different genomic regions. Journal of Evolutionary Biology, 29(1), 205-219. doi: 10.1111/jeb.12776

Fisher, R. A. (1937). The wave of advance of advantageous genes. Annals of Eugenics, 7(4), 355369. doi: 10.1111/j.1469-1809.1937.tb02153.x

Furrer, R. D., \& Pasinelli, G. (2016). Empirical evidence for source-sink populations: a review on occurrence, assessments and implications. Biological Reviews, 91(3), 782-795. doi: 10.1111/brv.12195

Gherardi, F., \& Barbaresi, S. (2000). Invasive crayfish: activity patterns of Procambarus clarkii in the rice fields of the Lower Guadalquivir (Spain). Archiv Für Hydrobiologie, 150, 153-168.

Gherardi, F., Tricarico, E., \& Ilhéu, M. (2002). Movement patterns of an invasive crayfish, Procambarus clarkii, in a temporary stream of southern Portugal. Ethology Ecology \& Evolution, 14(3), 183-197. doi: 10.1080/08927014.2002.9522739

Gilbert, K. J., \& Whitlock, M. C. (2015). Evaluating methods for estimating local effective population size with and without migration. Evolution, 69(8), 2154-2166. doi: 10.1111/evo.12713

González-Martínez, S. C., Ridout, K., \& Pannell, J. R. (2017). Range expansion compromises adaptive evolution in an outcrossing plant. Current Biology, 27(16), 2544-2551.e4. doi: 10.1016/j.cub.2017.07.007

Goudet, J., \& Jombart, T. (2015). Hierfstat: estimation and tests of hierarchical F-statistics. R Package Version 0.04-22. doi: https://CRAN.R-project.org/package=hierfstat

Gracianne, C., Jan, P.-L., Fournet, S., Olivier, E., Arnaud, J.-F., Porte, C., .. Petit, E. J. (2016). Temporal sampling helps unravel the genetic structure of naturally occurring populations of a 
phytoparasitic nematode. 2. Separating the relative effects of gene flow and genetic drift. Evolutionary Applications, 9(8), 1005-1016. doi: 10.1111/eva.12401

Graves, T., Chandler, R. B., Royle, J. A., Beier, P., \& Kendall, K. C. (2014). Estimating landscape resistance to dispersal. Landscape Ecology, 29(7), 1201-1211. doi: 10.1007/s10980-0140056-5

Hastings, A., Cuddington, K., Davies, K. F., Dugaw, C. J., Elmendorf, S., Freestone, A., ... Thomson, D. (2005). The spatial spread of invasions: new developments in theory and evidence. Ecology Letters, 8(1), 91-101. doi: 10.1111/j.1461-0248.2004.00687.x

Hendrickx, F., Maelfait, J.-P., \& Lens, L. (2003). Relationship between fluctuating asymmetry and fitness within and between stressed and unstressed populations of the wolf spider Pirata piraticus. Journal of Evolutionary Biology, 16(6), 1270-1279. doi: 10.1046/j.14209101.2003.00633.x

Hervé, M. (2019). RVAideMemoire: Testing and plotting Procedures for Biostatistics. R package version 0.9-73. Retrieved from https:/CRAN.R-project.org/package=RVAideMemoire

Hijmans, R. J. (2017). raster: geographic data analysis and modeling. R Package Version 2.6-7. doi: https://CRAN.R-project.org/package=raster

Huang, J., Tang, S., Cai, F., Lin, Y., \& Wu, Z. (2017). Microsatellite evidence of dispersal mechanism of red swamp crayfish (Procambarus clarkii) in the Pearl River basin and implications for its management. Scientific Reports, 7(1). doi: 10.1038/s41598-017-08552-3

Hulme, P. E. (2009). Trade, transport and trouble: managing invasive species pathways in an era of globalization. Journal of Applied Ecology, 46(1), 10-18. doi: 10.1111/j.13652664.2008.01600.x

Ingvarsson, P. K. (2001). Restoration of genetic variation lost - the genetic rescue hypothesis. Trends in Ecology \& Evolution, 16(2), 62-63.

Jombart, T. (2008). adegenet: a R package for the multivariate analysis of genetic markers. Bioinformatics, 24, 1403-1405. doi: 10.1093/bioinformatics/btn129

Kanarek, A. R., Webb, C. T., Barfield, M., \& Holt, R. D. (2015). Overcoming Allee effects through evolutionary, genetic, and demographic rescue. Journal of Biological Dynamics, 9(1), 15-33. doi: 10.1080/17513758.2014.978399 
Keller, S. R., \& Taylor, D. R. (2008). History, chance and adaptation during biological invasion: separating stochastic phenotypic evolution from response to selection. Ecology Letters, 11(8), 852-866. doi: 10.1111/j.1461-0248.2008.01188.x

Klopfstein, S., Currat, M., \& Excoffier, L. (2006). The fate of mutations surfing on the wave of a range expansion. Molecular Biology and Evolution, 23(3), 482-490. doi: 10.1093/molbev/msj057

Lawson Handley, L.-J., Estoup, A., Evans, D. M., Thomas, C. E., Lombaert, E., Facon, B., ... Roy, H. E. (2011). Ecological genetics of invasive alien species. BioControl, 56(4), 409.

Leblois, R., Pudlo, P., Néron, J., Bertaux, F., Reddy Beeravolu, C., Vitalis, R., \& Rousset, F. (2014). Maximum-likelihood inference of population size contractions from microsatellite data. Molecular Biology and Evolution, 31(10), 2805-2823. doi: 10.1093/molbev/msu212

Lee, C. E. (2002). Evolutionary genetics of invasive species. Trends in Ecology \& Evolution, 17(8), 386-391. doi: 10.1016/S0169-5347(02)02554-5

Lens, L., Dongen, S., Kark, S., \& Matthysen, E. (2002). Fluctuating asymmetry as an indicator of fitness: can we bridge the gap between studies? Biological Reviews, 77(1), 27-38. doi: 10.1017/S1464793101005796

Leung, B., \& Forbes, M. R. (1996). Fluctuating asymmetry in relation to stress and fitness: Effects of trait type as revealed by meta-analysis. Écoscience, 3(4), 400-413. doi: $10.1080 / 11956860.1996 .11682357$

Li, Y., Guo, X., Cao, X., Deng, W., Luo, W., \& Wang, W. (2012). Population genetic structure and post-establishment dispersal patterns of the red swamp crayfish Procambarus clarkii in China. PLoS ONE, 7(7), e40652. doi: 10.1371/journal.pone.0040652

Lockwood, J. L., Hoopes, M. F., \& Marchetti, M. P. (2007). Invasion ecology. Blackwell Publishing Ltd.

Lodge, D. M., Deines, A., Gherardi, F., Yeo, D. C. J., Arcella, T., Baldridge, A. K., ... Zeng, Y. (2012). Global introductions of crayfishes: evaluating the impact of species invasions on ecosystem services. Annual Review of Ecology, Evolution, and Systematics, 43(1), 449-472. doi: 10.1146/annurev-ecolsys-111511-103919 
Luikart, G., Allendorf, F. W., Cornuet, J.-M., \& Sherwin, W. B. (1998). Distortion of allele frequency distributions provides a test for recent population bottlenecks. Journal of Heredity, 89(3), 238-247. doi: 10.1093/jhered/89.3.238

Lynch, M., Conery, J., \& Burger, R. (1995). Mutation accumulation and the extinction of small populations. The American Naturalist, 146(4), 489-518.

Maciel, G. A., \& Lutscher, F. (2015). Allee effects and population spread in patchy landscapes. Journal of Biological Dynamics, 9(1), 109-123. doi: 10.1080/17513758.2015.1027309

Marques, M., Banha, F., Águas, M., \& Anastácio, P. (2015). Environmental cues during overland dispersal by three freshwater invaders: Eriocheir sinensis, Pacifastacus leniusculus, and Procambarus clarkii (Crustacea, Decapoda). Hydrobiologia, 742(1), 81-93. doi: 10.1007/s10750-014-1968-4

McRae, B. H., \& Beier, P. (2007). Circuit theory predicts gene flow in plant and animal populations. Proceedings of the National Academy of Sciences, 104(50), 19885-19890.

Messager, M. L., \& Olden, J. D. (2019). Phenotypic variability of rusty crayfish (Faxonius rusticus) at the leading edge of its riverine invasion. Freshwater Biology, O(0), 1-14. doi: 10.1111/fwb.13295

Ochocki, B. M., \& Miller, T. E. X. (2017). Rapid evolution of dispersal ability makes biological invasions faster and more variable. Nature Communications, 8, 14315. doi: $10.1038 /$ ncomms 14315

Palmer, A. R., \& Strobeck, C. (1986). Fluctuating Asymmetry: Measurement, Analysis, Patterns. Annual Review of Ecology and Systematics, 17, 391-421. Retrieved from JSTOR.

Paradis, E. (2010). pegas: an R package for population genetics with an integrated-modular approach. Bioinformatics, 26, 419-420.

Parmesan, C. (2006). Ecological and evolutionary responses to recent climate change. Annual Review of Ecology, Evolution, and Systematics, 37(1), 637-669. doi: 10.1146/annurev.ecolsys.37.091305.110100

Paulson, E. L., \& Martin, A. P. (2014). Discerning invasion history in an ephemerally connected system: landscape genetics of Procambarus clarkii in Ash Meadows, Nevada. Biological Invasions, 16(8), 1719-1734. doi: 10.1007/s10530-013-0621-x 
Peischl, S., \& Excoffier, L. (2015). Expansion load: recessive mutations and the role of standing genetic variation. Molecular Ecology, 24(9), 2084-2094. doi: 10.1111/mec.13154

Peischl, S., Kirkpatrick, M., \& Excoffier, L. (2015). Expansion load and the evolutionary dynamics of a species range. The American Naturalist, 185(4), E81-E93. doi: 10.1086/680220

Peniston, J. H., Barfield, M., \& Holt, R. D. (2019). Pulsed immigration events can facilitate adaptation to harsh sink environments. The American Naturalist, 704608. doi: 10.1086/704608

Peter, B. M., \& Slatkin, M. (2015). The effective founder effect in a spatially expanding population. Evolution, 69(3), 721-734. doi: 10.1111/evo.12609

Phillips, B. L. (2015). Evolutionary processes make invasion speed difficult to predict. Biological Invasions, 17(7), 1949-1960. doi: 10.1007/s10530-015-0849-8

Phillips, B. L., Brown, G. P., \& Shine, R. (2010a). Evolutionarily accelerated invasions: the rate of dispersal evolves upwards during the range advance of cane toads. Journal of Evolutionary Biology, 23(12), 2595-2601. doi: 10.1111/j.1420-9101.2010.02118.x

Phillips, B. L., Brown, G. P., \& Shine, R. (2010b). Life-history evolution in range-shifting populations. Ecology, 91(6), 1617-1627.

Phillips, B. L., Brown, G. P., Webb, J. K., \& Shine, R. (2006). Invasion and the evolution of speed in toads. Nature, 439(7078), 803.

Prentis, P. J., Wilson, J. R. U., Dormontt, E. E., Richardson, D. M., \& Lowe, A. J. (2008). Adaptive evolution in invasive species. Trends in Plant Science, 13(6), 288-294. doi: 10.1016/j.tplants.2008.03.004

R Core Team. (2018). R: A language and environment for statistical computing. Retrieved from https://www.R-project.org/

Ramalho, R. O., \& Anastácio, P. M. (2015). Factors inducing overland movement of invasive crayfish (Procambarus clarkii) in a ricefield habitat. Hydrobiologia, 746(1), 135-146. doi: 10.1007/s10750-014-2052-9

Rasband, W. (2012). ImageJ - Image processing and analysis in Java. Retrieved from http://rsb.info.nih.gov/ij/

Rousset, F. (1997). Genetic differentiation and estimation of gene flow from F-statistics under isolation by distance. Genetics, 145(4), 1219-1228. 
Savini, D., Occhipinti-Ambrogi, A., Marchini, A., Tricarico, E., Gherardi, F., Olenin, S., \& Gollasch, S. (2010). The top 27 animal alien species introduced into Europe for aquaculture and related activities. Journal of Applied Ichthyology, 26, 1-7.

Sax, D., Stachowicz, J., Brown, J., Bruno, J., Dawson, M., Gaines, S., ... Mayfield, M. (2007). Ecological and evolutionary insights from species invasions. Trends in Ecology \& Evolution, 22(9), 465-471. doi: 10.1016/j.tree.2007.06.009

Sexton, J. P., McIntyre, P. J., Angert, A. L., \& Rice, K. J. (2009). Evolution and ecology of species range limits. Annual Review of Ecology, Evolution, and Systematics, 40(1), 415-436. doi: 10.1146/annurev.ecolsys. 110308.120317

Simberloff, D. (2011). How common are invasion-induced ecosystem impacts? Biological Invasions, 13(5), 1255-1268. doi: 10.1007/s10530-011-9956-3

Simberloff, D., \& Gibbons, L. (2004). Now you see them, now you don't!-population crashes of established introduced species. Biological Invasions, 6(2), 161-172.

Skellam, J. G. (1951). Random dispersal in theoretical populations. Biometrika, 38(1/2), 196. doi: $10.2307 / 2332328$

Slatkin, M. (1993). Isolation by distance in equilibrium and non-equilibrium populations. Evolution, 47(1), 264. doi: 10.2307/2410134

Slatkin, M., \& Excoffier, L. (2012). Serial founder effects during range expansion: a spatial analog of genetic drift. Genetics, 191(1), 171-181. doi: 10.1534/genetics.112.139022

Souty-Grosset, C., Anastácio, P. M., Aquiloni, L., Banha, F., Choquer, J., Chucholl, C., \& Tricarico, E. (2016). The red swamp crayfish Procambarus clarkii in Europe: impacts on aquatic ecosystems and human well-being. Limnologica - Ecology and Management of Inland Waters, $58,78-93$.

Spear, S. F., Peterson, C. R., Matocq, M. D., \& Storfer, A. (2005). Landscape genetics of the blotched tiger salamander (Ambystoma tigrinum melanostictum). Molecular Ecology, 14(8), 25532564. doi: 10.1111/j.1365-294X.2005.02573.x

Strayer, D. L., D’Antonio, C. M., Essl, F., Fowler, M. S., Geist, J., Hilt, S., ... Jeschke, J. M. (2017). Boom-bust dynamics in biological invasions: towards an improved application of the concept. Ecology Letters, 20(10), 1337-1350. doi: 10.1111/ele.12822 
Szulkin, M., Bierne, N., \& David, P. (2010). Heterozygosity-fitness correlations: a time for reappraisal. Evolution. doi: 10.1111/j.1558-5646.2010.00966.x

Taylor, C. M., \& Hastings, A. (2005). Allee effects in biological invasions. Ecology Letters, 8(8), 895-908. doi: 10.1111/j.1461-0248.2005.00787.x

Tréguier, A., Roussel, J.-M., Bélouard, N., \& Paillisson, J.-M. (2018). Is it a hindrance for an invasive aquatic species to spread across scattered habitat patches? Aquatic Conservation: Marine and Freshwater Ecosystems, 28(3), 610-618. doi: 10.1002/aqc.2887

Van Dongen, S. (2006). Fluctuating asymmetry and developmental instability in evolutionary biology: past, present and future. Journal of Evolutionary Biology, 19(6), 1727-1743. doi: 10.1111/j.1420-9101.2006.01175.x

van Etten, J. (2017). R package gdistance: distances and routes on geographical grids. Journal of Statistical Software, 76(13), 1-21. doi: 10.18637/jss.v076.i13

Vitousek, P. M., D’antonio, C. M., Loope, L. L., Rejmanek, M., \& Westbrooks, R. (1997). Introduced species: a significant component of human-caused global change. New Zealand Journal of Ecology, 21(1), 1-16.

Walsh, P., Metzger, D., \& Higuchi, R. (1991). Chelex 100 as a medium for simple extraction of DNA for PCR-based typing from forensic material. Biotechniques, 10(4), 506-513.

Walther, G.-R., Post, E., Convey, P., Menzel, A., Parmesan, C., Beebee, T. J. C., ... Bairlein, F. (2002). Ecological responses to recent climate change. Nature, 416(6879), 389-395. doi: $10.1038 / 416389 \mathrm{a}$

Wang, J, Santiago, E., \& Caballero, A. (2016). Prediction and estimation of effective population size. Heredity, 117(4), 193-206.

Wang, Jinliang, \& Whitlock, M. C. (2003). Estimating effective population size and migration rates from genetic samples over space and time. Genetics, 163(1), 429-446.

Weir, B. S., \& Goudet, J. (2017). A unified characterization of population structure and relatedness. Genetics, 206(4), 2085-2103. doi: 10.1534/genetics.116.198424

Weiss-Lehman, C., Hufbauer, R. A., \& Melbourne, B. A. (2017). Rapid trait evolution drives increased speed and variance in experimental range expansions. Nature Communications, 8 , 14303. doi: $10.1038 /$ ncomms 14303 
Willi, Y., Fracassetti, M., Zoller, S., \& Van Buskirk, J. (2018). Accumulation of mutational load at the edges of a species range. Molecular Biology and Evolution, 35(4), 781-791. doi: 10.1093/molbev/msy003

Williams, J. L., Kendall, B. E., \& Levine, J. M. (2016). Rapid evolution accelerates plant population spread in fragmented experimental landscapes. Science, 353(6298), 482-485.

Williams, J. L., Snyder, R. E., \& Levine, J. M. (2016). The influence of evolution on population spread through patchy landscapes. The American Naturalist, 188(1), 15-26. doi: $10.1086 / 686685$

Yi, S., Li, Y., Shi, L., Zhang, L., Li, Q., \& Chen, J. (2018). Characterization of population genetic structure of red swamp crayfish, Procambarus clarkii, in china. Scientific Reports, 8(1). doi: 10.1038/s41598-018-23986-z

\section{Data accessibility}

Data available from the Dryad Digital Repository: https://doi.org/10.5061/dryad.3g5f4m0

\section{Author Contributions}

NB, JMP and EJP designed the research, all authors performed the research, NB and EJP analysed the data, NB, JMP and EJP wrote the paper. 


\section{Figures}

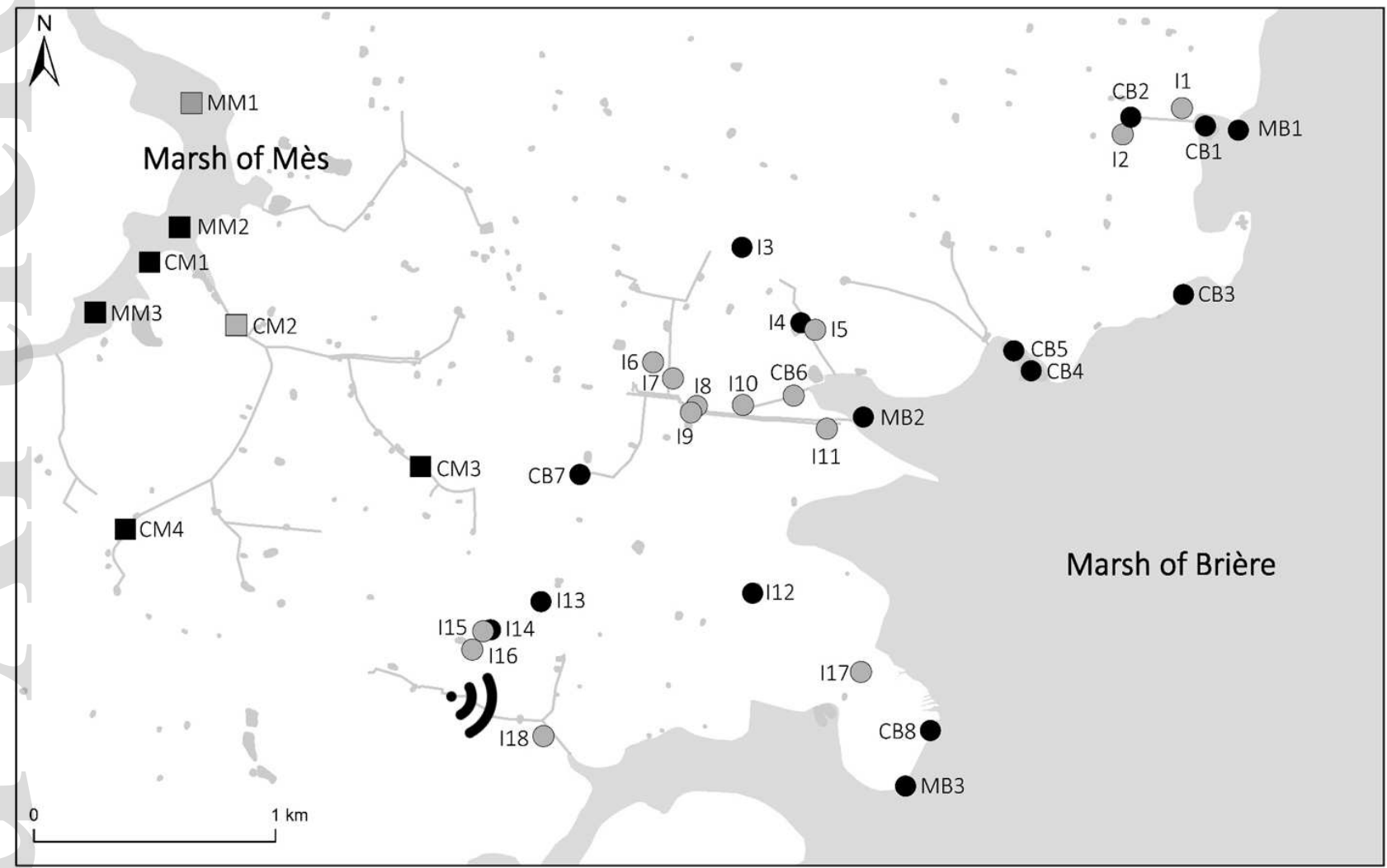

Fig. 1. Spatial location of the sampled crayfish populations. Historical maximal flooded areas of the marshes, non-sampled ponds, and watercourses are represented in grey. Circles and squares indicate the affiliation of the sampled crayfish populations to the networks of Brière and Mès, respectively. Among them, black symbols signal populations sampled both in 2014 and in 2016, and grey symbols are used for populations sampled only in 2016. The Wifi pictogram indicates the only known introduction site of red swamp crayfish in the study area. 


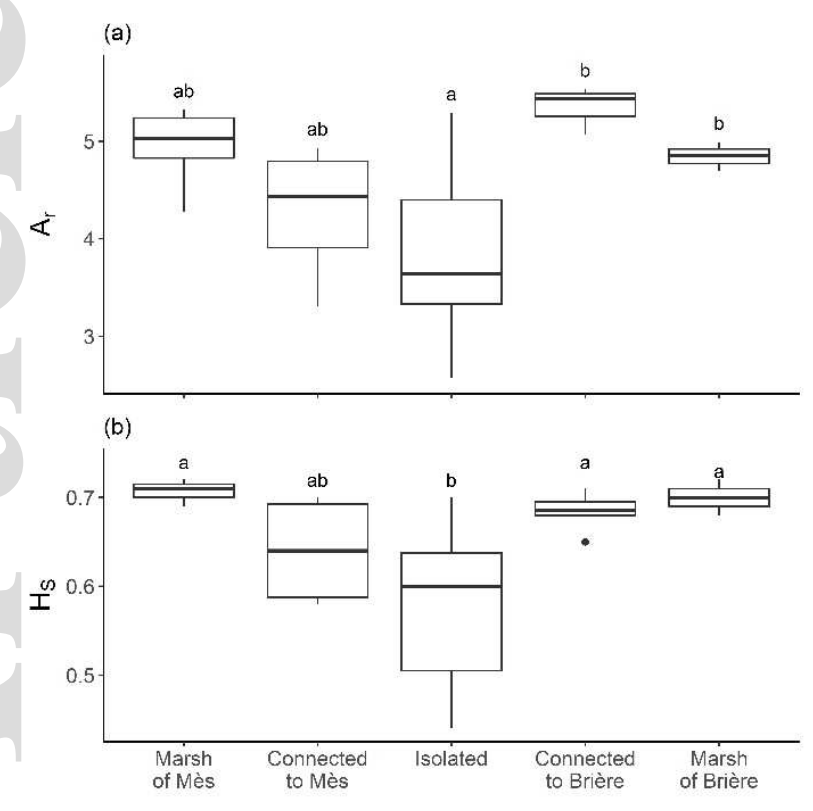

Fig. 2. Genetic variation between population categories: (a) allelic richness $\left(A_{r}\right)$, (b) heterozygosity $\left(\mathrm{H}_{\mathrm{S}}\right)$. Different letters denote significant post-hoc differences between categories $(\mathrm{p}<0.05$ after correction for multiple testing). The values for each population are available in Table S1, Supporting Information. 
(a) Genetic structure

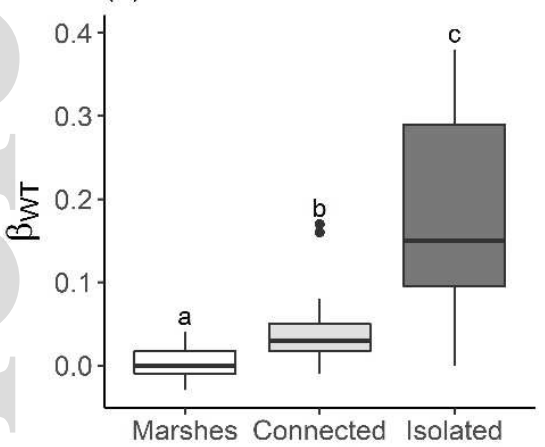

(d) LCP scenarios

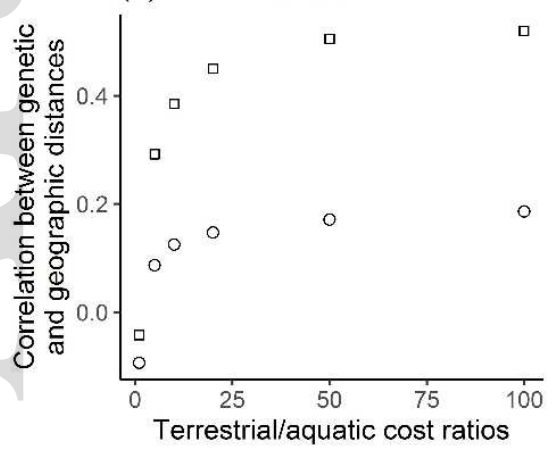

(b) IBD

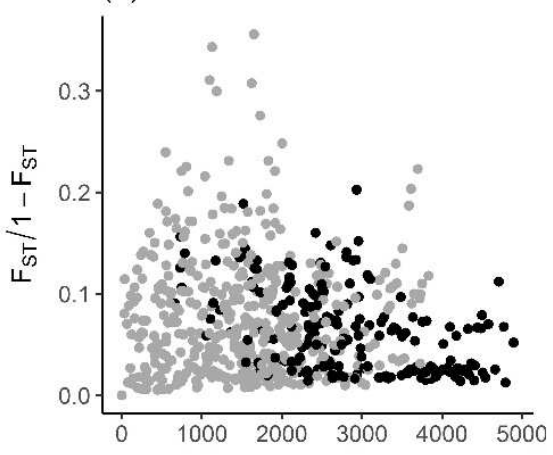

(e) Dispersal rates (c) LCP
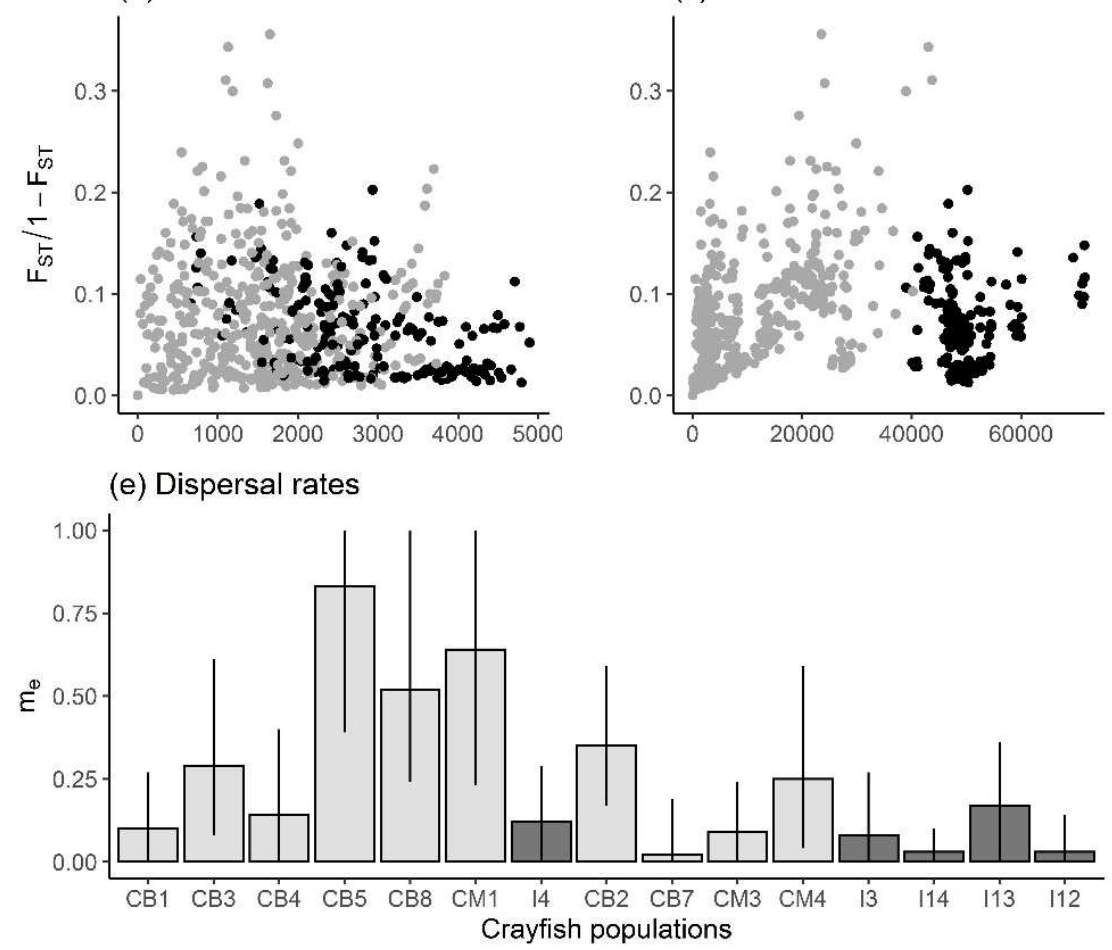

Fig. 3. Genetic structure and gene flow between crayfish populations. (a) Population differentiation $\left(\beta_{\mathrm{WT}}\right)$; different letters denote significant post-hoc differences between categories $(\mathrm{p}<0.05$ after correction for multiple testing); values for each population are available in Table S1, Supporting Information. (b) and (c) Correlations between genetic (linearised pairwise $\mathrm{F}_{\mathrm{ST}}$ ) and geographic distances between crayfish populations, with grey dots indicating pairs of populations from the same network and black dots indicating pairs of populations from different networks: (b) scenario of terrestrial and aquatic dispersal (IBD, terrestrial/aquatic cost ratio of 1/1). (c) scenario of aquatic dispersal only (least-cost distances, cost ratio of 100/1). (d) Correlation between genetic and geographic distances between crayfish populations, with increasing costs for crossing terrestrial habitats, all populations together (circles) or populations from the network of Brière only (squares). (e) Dispersal rates between the populations of the marshes and the populations of connected ponds (light grey bars) or the populations of isolated ponds (dark grey bars). Error bars are 95\% CI, and populations are ordered by LCP distance to the closest marsh. 
(a) Effective population sizes

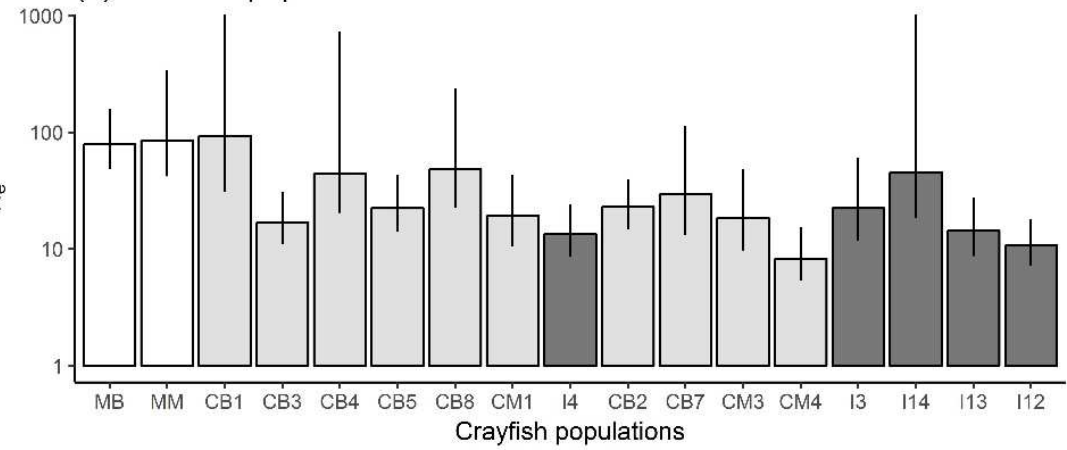

(c) FA estimates
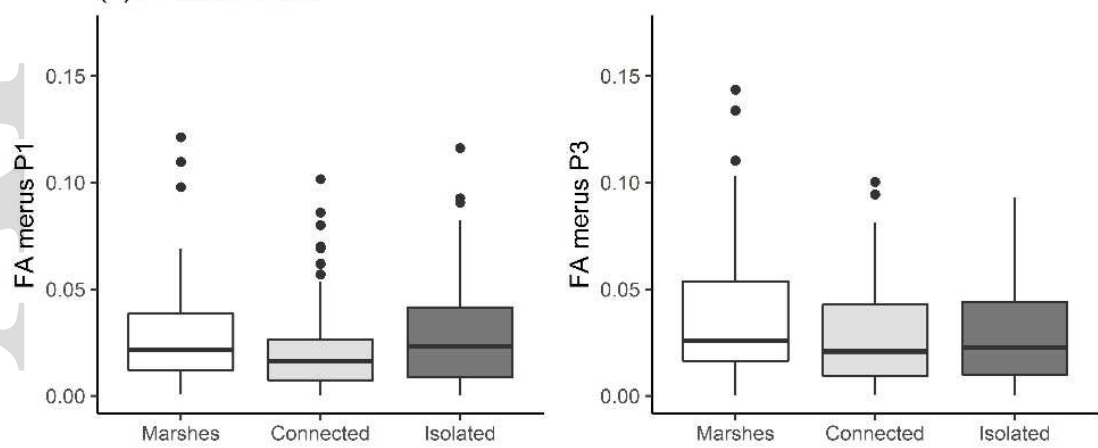

(b) Evolution of genetic diversity

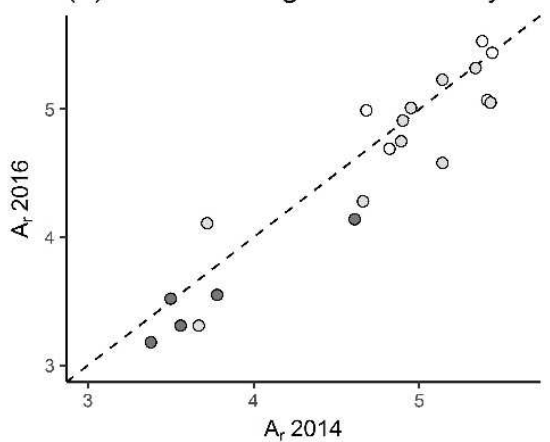

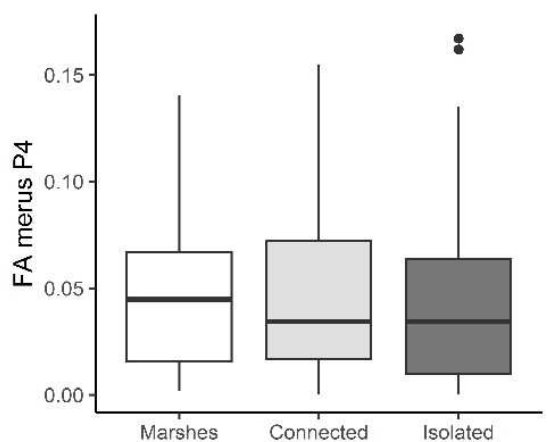

Fig. 4. Spatial and temporal estimates of genetic drift and its effects. (a) Estimates of effective population sizes in marshes (white bars, stations pooled per marsh), in connected ponds (light grey bars), or in isolated ponds (dark grey bars). Error bars are 95\% CI, and populations are ordered by LCP distance to the closest marsh. (b) Changes in allelic richness $\left(A_{r}\right)$ between 2014 and 2016 with dark grey, light grey, and white circles representing the populations of isolated ponds, connected ponds, and marshes, respectively. The dotted line represents $y=x$. (c) Unsigned FA indices per trait and per population category. 